\title{
ARTICLES
}

\section{COGNITIVE EXPLORATION OF 'TRAVELING' IN THE POETRY OF WIDAD BENMOUSSA}

\author{
Encarnación Sánchez Arenas \\ encarnacion.sanchez.arenas@gmail.com \\ University of Seville, Spain \\ Bacem A. Essam \\ literaryartrans@gmail.com \\ Ain Shams University, Egypt
}

Received October 10, 2018; Revised November 12, 2018; Accepted December 3, 2018

\begin{abstract}
The concept of motion is central to the human cognition and it is universally studied in cognitive linguistics. This research paper investigates concept of motion, with special reference to traveling, in the poetry of Widad Benmoussa. It mainly focuses on the cognitive dimensions underlying the metaphorical representation of traveling. To this end, the research conducts a semi-automated analysis of a corpus representing Widad's poetic collections. MetaNet's physical path is mainly used to reveal the cognitive respects of traveling. The personae the poetess assigns are found to pursue a dynamic goal through activation of several physical paths. During the unstable romantic relations, several travel impediments are met. Travel stops and detours, travel companions, paths in journey as well as changing travel destinations are the most stressed elements of 'Traveling' respects. With such a described high frequency of sudden departures and hopping, the male persona the poetess assigns evinces typical features of 'wanderlust' or dromomania.
\end{abstract}

Keywords: physical path, inner path, Traveling, conceptual metaphor, relativity, MetaNet.

Енкарнацьйон Санчес Аренас, Ессам Басем. Когнітивне дослідження концепту «Подорож» у поезії Відад Бенмуса.

Анотація. Концепція руху є центральною для людського пізнання й сьогодні вона $є$ поширеним предметом вивчення в когнітивній лінгвістиці. У цій статті представлене дослідження концепту руху, а особливу увагу приділено темі подорожі у віршах Відад Бенмуса, а саме: когнітивним вимірам, що лежать в основі метафоричного представлення мандрівки. Для досягнення цієї мети було проведено напівавтоматичний аналіз корпусу поетичних збірок Відад Бенмуса. Фізичний шлях MetaNet головно застосовано для виявлення когнітивних аспектів подорожі. Установлено, що персонажі, про яких пише поетеса, переслідують динамічну мету через активацію декількох фізичних шляхів. Під час їхн іх нестабільних романтичних стосунків, трапляються перешкоди на шляху до подорожей. 3'ясовано, що найбільш виділеними елементами аспектів «подорожі» є: зупинки й об'їди під час подорожей, супутники, шлях в дорозі, а також зміна туристичних напрямків. Ураховуючи описану високу частоту раптових від’їдів і поворотів, можна стверджувати, що особистість чоловіка, про якого пише поетеса, характеризують такі основні риси, як «нестримний потяг до мандрівки» або дромоманія.

(C) Arenas, Encarnación Sánchez; Essam, Bacem A, 2018. This is an Open Access article distributed under the terms and conditions of the Creative Commons Attribution 4.0 International Licence (http://creativecommons.org/licenses/by/4.0). East European Journal of Psycholinguistics, 5(2), 6-15. https:/doi.org/10.5281/zenodo.2583544 
Ключові слова: фізичний шлях, внутрішній шлях, подорож, концептуальна метафора, вidносність, MetaNet.

\section{Introduction}

Because motion is derived from universal bodily experiences, it is a wellestablished concept in the human cognition. Typically associated with the concept of space, motion takes an object, a displacement and a path. Whenever an object or an entity moves, there must be starting and ending points, in the space, the distance between which is a 'path'. Traveling represents a special case of motion in which a 'traveler' moves from a 'source' location to a 'goal' location and passes by a 'path'. 'Life' is conceptually considered a 'journey' in which 'people' are 'travelers'. This paper investigates the motion-related conceptual metaphors in Widad's poetry by using a list of motion representative words, retrieved from MetaNet and Linguistic Inquiry and Word Count (LIWC), with emphasis placed on the physical path.

Widad Benmoussa published several collections of poems. Her books are entitled "I Have A Root In The Air" (2001), "Between Two Clouds" (2006), "I Opened It On You" (2007), "A Storm In A Body" (2008), "I Hardly Lost My Narcissism" (2010), "I Stroll Along This Life" (2014) and "I Once Had A Heart" (2017). Most of these books have been analyzed to conclude about the psycholinguistic signature of the poetess (Arenas, 2018). Postulating that Widad's poetry reflects a unique case of 'travel' realization, we analyze the metaphorical usage of paths to retrieve the deeper orientation in the poetess' cognition of the spatiotemporal elements of the world. This implicates on using the source-path-goal combination. Section 2 introduces the Conceptual Metaphor Theory (Lakoff and Johnson, 2008), MetaNet, and the basic of LIWC-2015 (Carey et al., 2015; Pennebaker et al., 2015). The methodology is explained in section 3. The next sections view and discuss the findings before conclusions are drawn.

\section{Theoretical Preliminaries}

\subsection{Conceptual Metaphor Theory}

Space, motion and time are identified as universal domains in the human cognition because they are physically experienced, very often, across cultures and languages. Thus, any linguistic realization relevant to these domains is a reflection of a universal cognitive pattern. The linguistic instantiations of these domains, be they lexemes, argument structure or grammatical constructs, were studied under the theory of domains, image schema, frames, prototypicality, mental spaces and conceptual metaphors (Lakoff and Johnson, 2008). Evidence from neurolinguistics supports that the left anterior inferior parietal lobe and the left amygdala are activated more by metaphorical sentences than by literal ones. The left amygdala is a structure known to be involved in the processing of emotions and emotional language while the inferior parietal lobe is concerned with language, mathematical operations and body image (Goldman, 2014; Santarpia et al., 2006).

The Conceptual Metaphor Theory (CMT) proposed that the most central metaphors are grounded in bodily experience. The classic conceptual metaphor LIFE 
IS A JOURNEY, for instance, has a source domain which is an emergent product of various bodily actions whereby people start from a point, travel along a path, and reach a destination, called the SOURCE-PATH-GOAL image schema. This scheme reflects not just what happens when people move their entire bodies from point $A$ to $B$, but whenever people reach out to grasp an object, or move their eyes from one location to another. It might be expected that these metaphors would be shared by different languages and that abstract concepts are represented by image schemas from concrete domains (Forceville, 2016; Gibbs, 2011; Lakoff and Johnson, 2008).

CMT, within the original Lakoff-Johnson framework, emphasizes concepts instead of words. CMT emphasizes the universal, mechanical, and monolithic aspects of embodiment and stresses the role of universal bodily experience. Identification of such conceptual metaphors adopted, at the very beginning, a top-down approach through using quantitative and intuitive qualitative metaphor analysis. This approach populated a list of general metaphors tenets, which can be expanded further, to include specific ones. Given that the bottom-up approach of metaphor analysis entertains the assumption that metaphors at the linguistic level are characterized by irregularity attributed to many subtle differences in meaning, computational detection of metaphors, and their constituents, enabled this approach. Recently, mapping metaphor and metaphoricity have been applauded in megaprojects such as MetaNet, CogMod, and VisMet (Baicchi, 2017; David et al., 2017; Lakoff, 2014). MetaBank (Martin, 1994), ATT-Meta system databank (Lee and Barnden , 2001) and the Hamburg Metaphor Database (Lönneker-Rodman 2008) are other examples of projects which commensurate with the cognitive linguistic perspective of conceptualizing metaphors. All the aforementioned projects adopt a top-down approach, through the use of a manually collected and annotated Master Metaphor List. Metaphors, in MetaNet, are, however, meant to be formalized in a scalable network by enabling a bottom-up datadriven approach to avoid much of the criticism leveled at the basics of the CMT (Kövecses, 2008; Stickles et al. 2016).

\subsection{MetaNet}

MetaNet, a large structured repository of conceptual metaphors, has integrated CMT and Frame Semantics in a single language resource to facilitate larger-scale, finer-grained corpus approaches to analyzing metaphors. MetaNet (MN) has developed formal representations of metaphors as mappings from the Source domain (based in shared embodied experiences) to the Target domain (more conceptually abstract and viewpoint-dependent). Both the Source and Target domains are represented as frames, which are schematic representations of different kinds of experiences, objects and events. The MN repository represents the complex conceptual network that speakers of particular language have as comprising interconnected frames and metaphors.

Frames, in MN, are further divided into two types of conceptual structures: Scenes and Perspectives. Scenes provide structural and semantic information (i.e. roles and processes) while perspective frames specify the values of the $\mathrm{x}$-schema role of the related scenes, which constitute the possible additional temporal and causal values of the state dynamics of an eventuality. The hypothetical model of the relationships between conceptual structures in MN draws upon the Cascade Theory (David et al., 2016; Stickles et al., 2016). 
Frames are composed in a network with hierarchical, structure-defining and nonhierarchical relations to define frame-frame relations. Structure-defining relations are the ontological relations that constitute the hierarchy among frames (e.g., inheritance and composition). In MN, these relations are 'is subcase of', 'make use of' and 'is a subprocess of'. However, $\mathrm{MN}$ assigns several variants to 'makes use of', which are 'incorporates as a role', 'has affordance of', 'is a process that makes use of' and 'is a subscale of'. The non-hierarchical relations exist between sister frames with a common parent; indicating that the interacting relation is suggestive of a causal or temporal manner. These relations are 'is a subprocess of', 'is a perspective on', 'is in causal relation with', 'precedes', 'mutually inhibits', and 'is in scalar opposition to'. Therefore, MN further divides the representation of frames into two types: Scenes and Perspectives. Scenes provide structural and semantic information (i.e. roles and processes) while perspective frames specify the values of the $\mathrm{x}$-schema role of the related scenes, which constitute the possible additional temporal and causal values of the state dynamics of an eventuality. For any particular scene, a frame's structure must include particular structural components: entity role(s); non-entity role(s); an executing schema, or X-schema (a process frame) and Inferences. Perspectives include X-schema stages as well as causal variants of those stages (Stickles et al., 2016).

Similar to the organization of frames, the internal structure of a metaphor constitutes its source and target domains (which add up to a linguistic metaphor), relations between two metaphors and characteristic are in- formed by the relations between their respective frames. Metaphors are composed in a network with hierarchical, structure-defining, and non-hierarchical relations similar to the network governed by relations between frames. Linguistic metaphor (LM) is a linguistic expression that instantiates a conceptual metaphors linguistically, to be distinguished from visual metaphors. Lexemes evoking theft, such as in stealing time, robbed me of my health, and poached his idea, may entail that time, health, and ideas are valuable things that can be 'taken'. LMs constitute three different grammatical constructions: subject-verb construction, passive construction and adjective noun construction (Stickles et al., 2016).

Metaphor-to-metaphor relations do function to link individual metaphors for effectively defining larger metaphor networks. By adding inferential structure to either domain, additional entailed metaphors of increasing specificity are produced. Metaphors relation types are: 1) 'is both a source and target subcase of' 2) 'is a source subcase of' 3) 'is a target subcase of 4) 'is a mapping within' 5) 'makes use of' 6) 'has as transitive subpart 7) 'is an entailment of' 8) 'is in a dual relationship with.' When in doubt as to which of the above specific relations applies, one of the following relations may be used: 9) 'is in some source relation to' 10) 'is in some target relation to' and/or 11) 'is in some way related to.' (MetaNet Official Website).

\subsection{Linguistic Inquiry and Word Count (LIWC) and Poetic Stylometry}

Poetic Stylometry is the study of the authorial style of poets. Psychometrically speaking, the individual usage of pronouns, prepositions, articles, conjunctions, auxiliary verbs, and a few other esoteric categories can be reflective of personality and psychological features. Although corpus tools have been used to conclude 
psychological attitudes of poets, results have been improved when LIWC's categorized dictionary was applied. LIWC is introduced to analyze texts for concluding about the psychological signature of the writer via utilizing 120 lexica, categorized and validated on the principles of social psychology. By analyzing the writing content, LIWC measures algorithmically four perspectives: analytical thinking, clout, authenticity and emotionality (Pennebaker et al., 2015; Tausczik and Pennebaker, 2010). We use LIWC-2015 to analyze the general psychological profile of Widad Benmoussan and the main personae she creates.

\section{Methodology}

This study conducts quantitative and intuitive qualitative metaphor analyses of motion-related conceptual metaphors in the poetic collections of Widad Benmoussa. To do so, LIWC-2015 is, first, used to measure and define incidence of motion and space in Widad's poetry. Much as the internal lexica of LIWC-2015 were used to conclude the stylometric signature of the poet, the relativity-based lexica were used to generate seeding lexemes for computationally retrieving travel-based metaphorical phrases from Widad's poems. Second, the travel-expressing poetic lines are annotated for the identification of traveler/journeyer, travel_event, travel_stops, locations_along journey, travel_difficulties, travel_companion, manner_of_journey, travel_destination, path_traced_by_sequence_of_motion and vehicles_in_journey. An intuitive qualitative metaphor analysis was then conducted to define the parameters and perception of traveling in Widad's metaphoric conceptualization.

\section{Results and Discussion}

Related to the metaphor of "Human Life Is A Journey", for instance, it is rational to expect "Romantic Relationship Is A Journey" as a metaphor-to-metaphor target relation. Travelers are conceptually mapped to Lovers while a vehicle is conceptually mapped to Relationship. Common Destinations is conceptually mapped to Common Life Goals while Impediments to Travel is conceptually mapped to Relationship Difficulties.

Applying frame-to-frame relations to the "physical path" frame, it makes use of 'Source-path-goal' landmark, which is a subcase of Trajector landmark, Figure ground and spatial relation respectively. This denotes partial information of frame structure among the above mentioned frames. 'Maze', 'circular path' and 'paths out of a locations' are subcases of the frame "physical path" itself via inheritance. Although both frame-frame relations demonstrate structure-defining relations, inheritance encodes a full incorporation of the parent frames (Figure 1). Within this network, several conceptual metaphors are populated. As a frame, its lexical units are path, route, way, pathway, bridge, passage, road, trail, street, avenue, highway, track, aisle, bridge, fast track, freeway, toll road, superhighway, slow lane, fast lane, byway. These nouns can define the entity relation(s) a frame scene possess while verbs, in the retrieved metaphorical sentences, can define the dynamic x-schema of the scene structure. The superordinate words of these lexical words are used to define the conceptual metaphors they might generate. All these items conclude the linguistic metaphors and their role type constraint violation. 


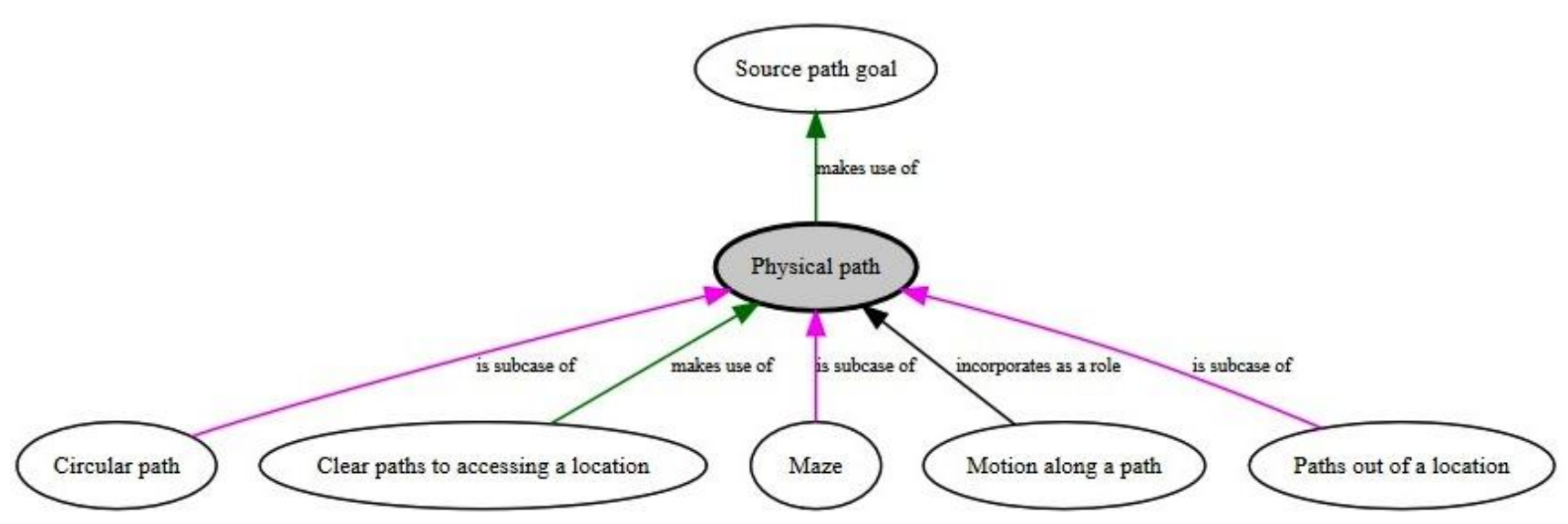

Fig.1. Frame-to-frame relations of "physical path" in MetaNet

Extraction of the literary devices and words which denote explicitly and/or implicitly reference to travel as a concept, traveler/journeyer, travel event or destination was conducted. Widad's usage of physical paths was annotated and analyzed. Representations of LIWC-driven results of relativity-expressing words in Widad's poetry are shown in the appendices. The following excerpts are concordanced examples of path and travel demonstration in Widad's poems.

As if I had inspired from you

Furtively, the virtue of detachment

And started merging all rivers

To collect the reflected envisage

Of our faces within a single frame.

As if I cursed all women who had mingled

Some of their lipsticks into your cells.

In these poetic lines, published in Widad's book "I Stroll Along This Life" (2014:103)" , the female persona expresses her reaction to the desire to leave of her beloved. Therefore, she had inspired from him, furtively and cunningly, the virtue of detachment too. She weeps her fruitless attempts for being reunited with him by attempting to merge rivers all over the world to collect the envisage of their faces, reflected within a single water page. This departure inclination, in her opinion, is attributed to the mundane womanizing nature of her beloved who consumed tons of women's lipstick into his lips by virtue of free kissing. Thus, the traveler is the male lover and travel destinations are women lips.

The poetess continues in "I Have A Root In The Air" (2001:62), page 62, to extend the voice of the female lover, who invites her beloved not to postpone his plans of travel, back to her, over the wing of nostalgia. She encourages him come to her with a moon face carrying, with him, the thrilled mountains which used to shake jubilantly for her.

Don't postpone your traveling plans

Over the wing of nostalgia

And come to me with a moon face 
Carrying, with you, the thrilled mountains

Which did shake jubilantly for me

Thus, the travel vehicle is the wing of nostalgia while the female lover herself is the travel destination and stop. The travel companions are, however, the longing thrilled mountains of the poetess' lover. Although the metaphoric reference to the bodily robust or muscular masculine parts of her beloved is unclear, phallic reference to their history of their play-off, which aroused them adequately; causing erection and pleasure is probable.

Widad Benmoussa carries on, in "I Have A Root In The Air" (2001:118) extends this metaphor from a persona's point of view. The female persona asks, rhetorically, about whom she may address to get her lover not to postpone his traveling plans, back to salvation, immortality and liberation while her destiny is to live on a butterfly wing; traveling to every corner of the world without any signs of tiresomeness or boredom.

To whom I draw salvation,

Immortality and liberation,

On a butterfly wing; traveling

To every corner of the world

Without any signs of boredom?

The poetess enhances her desire to reach her departing lover by composing, in "I Have A Root In The Air" (2001:98):

I am the one who never

Get bored of traveling to you

There lives a rose which keep

On counting my steps. Shall

Its hopes of seeing us be

Also dashed?

Her searching journeys, over the physical and metaphysical paths, to reach her ex-lover continues in "I Have A Root In The Air" (2001: 111-112)".

I collect my soft whine

To travel after your shade

In every stop for reaching you

The poems seems to be spoken by a female traveler who wishes to cut a journey to reach her ex-lover, she admires ironically the consistent response of her companions: the butterflies. The poetess composes in her book "I Stroll Along This Life" (2014: 105)",

If I were to choose from the beings, Which accompanied me on the travel path,

I will definitely choose the butterflies,

They were clapping

For every dreadful mistake I had made

On the vehicle of love 
All in all, the decision of the poetess' lover to run away from her and jump into the world of the unknown is attributed to his 'wanderlust'. The female persona enumerates her endless trials to keep their romantic nest warm and captivating and to eradicate any push factors that might repel him. She also questions the originality of the pull factors in the external world that he prefers. Throughout her poetic lines, the physical and virtual paths taken are all natural elements of which butterfly's wings, rivers, skies and winds are most tracked in their re-espousing journey.

The traveling path, which is consistently described, is the oft-visited road most taken by the two lovers towards and away from each other. However, the poetess is the punctual journeyer who traces back the steps of her ex-lover. The other physical paths her ex-lover takes is hovering and hopping for other womanly pleasure sources. This back and forth motions along circular and linear paths create a maze, which detracts the two lovers away from each other and adds up to the pronounced difficulties of traveling. Impediments to travel are conceptually mapped to relationship difficulties. The companions of 'travel' in the poem are roses and butterflies.

The poetess thus enables the "ROMANTIC RELATIONSHIP IS A JOURNEY" as a metaphor-to-metaphor target relation. Travelers are conceptually mapped to Lovers while a Vehicle is conceptually mapped to Relationship.

\section{Conclusion}

The poetess creates male and female personae that pursue a dynamic goal by using several physical paths. Through their unstable romantic relation, several travel impediments are met. Travel stops and detours, travel companions, paths in journey as well as changing travel destinations are the most stressed elements of 'Traveling' respects. With such a described high frequency of sudden departures and hopping, the poetess' lover is implicitly diagnosed with 'wanderlust' or dromomania.

The decision of the poetess' lover to run away from her and jump into the world of the unknown is attributed to his 'wanderlust'. The poetess enumerates her endless trials to keep their romantic nest warm and captivating and to eradicate any push factors that might repel him. She also questions the originality of the pull factors in the external world that he prefers. Throughout her poetic lines, the physical and virtual paths taken are all natural elements of which butterfly's wings, rivers, skies and winds are most tracked in the re-espousing of their journey.

Much as we recommend the usage of psycholinguistic tools and CMT framework to re-read literature, the metaphorically rich poetic discourse is encouraged to be used as a source for identification and detection of metaphorical mappings.

\section{References}

Arenas, E. S. (2018). Exploring Pornography in Widad Benmoussa's Poetry Using LIWC and Corpus Tools. Sexuality \& Culture, 1-18. 
Baicchi, A. (2017). The Relevance of Conceptual Metaphor in Semantic Interpretation. estetica. studi e ricerche, 7(1), 155-170.

Carey, A. L., Brucks, M. S., Küfner, A. C., Holtzman, N. S., Back, M. D., Donnellan, M. B., ... \& Mehl, M. R. (2015). Narcissism and the use of personal pronouns revisited. Journal of Personality and Social Psychology, 109(3), e1.

David, O., \& Matlock, T. (2018). Cross-linguistic automated detection of metaphors for poverty and cancer. Language and Cognition, 10(3), 467-493.

David, O., Lakoff, G., \& Stickles, E. (2016). Cascades in metaphor and grammar. Constructions and Frames, 8(2), 214-255.

Essam, B. A. (2016). Nizarre Qabbani's original versus translated pornographic ideology: A corpus-based study. Sexuality \& Culture, 20(4), 965-986

Forceville, C. (2016). Conceptual metaphor theory, blending theory, and other cognitivist perspectives on comics. The visual narrative reader, 89-114.

Gibbs Jr, R. W. (2011). Evaluating conceptual metaphor theory. Discourse processes, 48(8), $529-562$.

Kövecses, Z. (2008). Conceptual metaphor theory: Some criticisms and alternative proposals. Annual review of cognitive linguistics, 6(1), 168-184.

Lakoff, G. (2014). Mapping the brain's metaphor circuitry: Metaphorical thought in everyday reason. Frontiers in Human Neuroscience, 8, 958.

Lakoff, G., \& Johnson, M. (2008). Metaphors we live by. University of Chicago press.

Lee, M. G., \& Barnden, J. A. (2001). Mental metaphors from the Master Metaphor List: Empirical examples and the application of the ATT-Meta system. Cognitive Science Research Papers University of Birmingham CSRP.

Lönneker-Rodman, B. (2008). The Hamburg metaphor database project: issues in resource creation. Language Resources and Evaluation, 42(3), 293-318.

Martin, J. H. (1994). Metabank: A knowledge-base of metaphoric language conventioms. Computational Intelligence, 10(2), 134-149.

MetaNet Web Site: https://metanet.ic si.berkeley.edu/metanet/

Pennebaker, J. W., Boyd, R. L., Jordan, K., \& Blackburn, K. (2015). The development and psychometric properties of LIWC2015. Retrieved from https://repositories.lib.utexas.edu/ handle/2152/31333

Santarpia, A., Blanchet, A., Venturini, R., Cavallo, M., \& Raynaud, S. (2006, August). La catégorisation des métaphores conceptuelles du corps. In Annales Médico-psychologiques, revue psychiatrique (Vol. 164, No. 6, pp. 476-485). Elsevier Mas son.

Stickles, E., David, O., Dodge, E. K., \& Hong, J. (2016). Formalizing contemporary conceptual metaphor theory. Constructions and frames, 8(2), 166-213

Tausczik, Y. R., \& Pennebaker, J. W. (2010). The psychological meaning of words: LIWC and computerized text analysis methods. Journal of Language and Social Psychology,29(1), $24-54$.

\section{Sources}

Benmoussa, W. (2001). I have Roots in Air (in Arabic). Morocco: Ministry of Culture.

Benmoussa, W. (2006). Between Two Clouds (in Arabic and French). Morocco: Marsam Publishing House.

Benmoussa, W. (2007). I Opened It on You (in Arabic). Morocco: Marsam Publishing House.

Benmoussa, W. (2008). Storm in a Body (in Arabic). Morocco: Marsam Publishing House.

Benmoussa, W. (2010). I Hardly Lost my Narcissism (in Arabic). Syria: Ward Publishing House.

Benmoussa, W. (2014). I Stroll Along This Life. Morocco: Tobkal Publishing House 
Appendix 1

LIWC-2015's identification of relativity-expressing words in Widad's poems

\begin{tabular}{ll}
\hline Category & \multicolumn{1}{c}{ Representative words } \\
\hline Relativity & sun, coming, remote, land, on, off, leave, in, inferior, out, come, back, \\
& whenever, moment, remotely, spring, long, edge, always, days, deeply, \\
& climb, surface, world, flight, fly, infinity, filled, flow, morning, small, \\
& $\begin{array}{l}\text { escape, into, under, away, after, still, room, distant, far, dance, up, } \\
\text { danced, little, while, intersection, walk, link, goes, never, eternity, end, } \\
\text { travel, until }\end{array}$
\end{tabular}

Motion coming, leave, come, climb, flight, fly, flow, escape, dance, danced, walk, goes, travel

Space remote, land, on, off, in, inferior, out, back, remotely, long, edge, deeply, surface, world, filled, small, into, under, away, room, distant, far, up, little, intersection

Time back, whenever, moment, spring, always, days, infinity, morning, after, still, while, never, eternity, end, until

Religion spirit, hell, paradise, angels, prayer

Past-focus lost, were, remember, did, danced, knew, told

Present- is, leave, watch, come, are, hope, be, do, live, lives, realize, tell, thinks, focus see, have, ask, am, flow, cannot, understand, looks, look, does, knows, walk, goes, am, travel

Future- coming, will, hope, prayer

focus

Appendix 2

\begin{tabular}{lllllll}
\hline Book Title & $\begin{array}{l}\text { I Have a } \\
\text { Root in } \\
\text { the Air }\end{array}$ & $\begin{array}{l}\text { Between } \\
\text { Two } \\
\text { Clouds }\end{array}$ & $\begin{array}{l}\text { I Opened } \\
\text { It on You }\end{array}$ & $\begin{array}{l}\text { A Storm } \\
\text { in a } \\
\text { Body }\end{array}$ & $\begin{array}{l}\text { I Hardly } \\
\text { Lost My } \\
\text { Narcissism }\end{array}$ & $\begin{array}{l}\text { I Stroll } \\
\text { Along } \\
\text { This Life }\end{array}$ \\
\hline $\begin{array}{l}\text { Publication year } \\
\text { Word count }\end{array}$ & $\mathbf{2 0 0 1}$ & $\mathbf{2 0 0 6}$ & $\mathbf{2 0 0 7}$ & $\mathbf{2 0 0 8}$ & $\mathbf{2 0 1 0}$ & $\mathbf{2 0 1 4}$ \\
$\begin{array}{l}\text { Psychological } \\
\text { attribute }\end{array}$ & & 2449 & 1381 & 3500 & 750 & 4518 \\
$\quad \begin{array}{lllll}\text { Analytic } \\
\text { Clout }\end{array}$ & 84.04 & 80.27 & 68.11 & 76.47 & 62.96 & 75.34 \\
Authentic & 53.11 & 51.96 & 65.22 & 68.63 & 67 & 44.29 \\
Tone & 69.72 & 74.71 & 39.05 & 65.73 & 80.38 & 75.75 \\
Stylistic features & 20.56 & 22.6 & 19.3 & 29.1 & 55.96 & 22.01 \\
Focus past & 2.02 & 2.49 & 4.06 & 2.23 & 1.33 & 2.99 \\
Focus present & 9.16 & 9.76 & 7.68 & 9.11 & 10.27 & 8.01 \\
Focus future & 0.56 & 1.1 & 0.43 & 1.71 & 0.67 & 1.68 \\
Relativity & 14.41 & 13.88 & 13.83 & 15.09 & 13.2 & 13.75 \\
Motion & 2.89 & 2.94 & 1.74 & 2.66 & 2.8 & 2.21 \\
Space & 8.15 & 7.8 & 7.53 & 8.83 & 7.73 & 8.43 \\
Time & 3.47 & 3.39 & 4.63 & 3.83 & 2.67 & 3.32
\end{tabular}

